\title{
De processuelle normers betydning for virkeliggørelsen af den materielle strafferet
}

\author{
Af adjunkt, lic. jur. HANS GAMMELTOFT-HANSEN, Kфbenhavn
}

1. Strafferetten og straffeprocesretten er uløseligt forbundne. Uden straffeprocessen ville den materielle strafferet være, ikke blot en torso, men som en sjæl uden krop - et sæt af idéer, intentioner og normer uden $\mathrm{k} \phi \mathrm{d}$ og blod.

Straffeprocessen ville på sin side være meningsl $\phi$ s uden strafferetten, som er dens egentlige årsag og mål. — Undertiden hævdes det, at strafferetsplejen kan beskrives enten som tjenende strafferettens realisering, eller som et konkret udtryk for individets beskyttelse over for statsmagten. Denne alternative opstilling kan måske rumme pædagogiske fordele, men er begrebsmæssigt forkert. Hvordan man end vender og drejer det, er det alene eksistensen af en materiel strafferet, der fordrer procesrettens tilkomst. Ved den nærmere udformning af straffeprocesretten kan man så lægge st $\varnothing$ rre eller mindre vægt på individets retsbeskyttelse. Men dette er sekundært —ikke i betydning og vægt, men i årsagskædens rækkef $\varnothing$ lge.

Er straffeprocessen meningsl $\varnothing$ s uden strafferetten, ville strafferetten til gengæld ikke kunne eksistere andre steder end på papiret, såfremt der ikke gaves en straffeprocesret. For få år siden udsendte amerikaneren Herbert G. Packer en opsigtsvækkende bog om straffens begrænsning (The Limits of Criminal Sanction. Stanford University Press, 1968). Han understreger heri med megen vægt, at den stadige styrkelse af tiltaltes stilling under strafforf $\varnothing$ lgningen efterhånden gør straffeprocessen til et uhåndterligt middel til at behandle mange straffesager og sagskategorier. Det interessante er imidlertid, at han deraf drager den konklusion, at det under disse omstændigheder må være konsekvensen simpelthen at foretage en indskrænkning af det strafbares område.- Stærkere kan straffeprocessens betydning for virkeligg $\phi$ relsen af den materielle strafferet næppe understreges.

Jeg skal her s $\phi$ ge nærmere at belyse en række - i $\phi$ vrigt til dels modstridende - sider af denne vidtstrakte indflydelse, som tilskrives det straffeprocessuelle system.

Ved den nærmere fortolkning af udtrykket ,virkeliggфrelse af den materielle strafferet" byder to muligheder sig til.

Artiklen er manuskript til forfatterens forelæsning over et opgivet emne for den juridiske licentiatgrad, afholdt den 21. september 1973 på Københavns Universitet. 
Den materielle strafferets funktion kan summarisk beskrives som fastsættelsen af betingelserne for straf og andre lignende retsfolger, samt fastsættelsen af rammerne for og indholdet af disse retsf $\varnothing$ lger. Opfattet på denne måde kan de processuelle reglers betydning for den materielle strafferets virkeligg $\varnothing$ relse formuleres i følgende spørgsmål: Hvorledes fremmer (eller modvirker) de processuelle regler konstateringen i den konkrete sag af, hvorvidt betingelserne for at pålægge en bestemt sanktion er til stede?

Man kunne også opfatte udtrykket ,den materielle strafferet“ generelt som selve det strafferetlige system. Ethvert system har lakuner; det gælder også det strafferetlige. I et vist omfang udfyldes disse lakuner imidlertid af bestemmelser og regler, der sædvanligvis henf $\phi$ res til straffeprocessen. Sådanne processuelle regler kan derfor siges at bidrage til virkeligg $\varnothing$ relsen af den materielle strafferet gennem supplering og præcisering af det strafferetlige system. Man kunne også udtrykke det på den måde, at visse processuelle regler er bærere af materielt strafferetlige funktioner; og det skyldes i reglen en kodifikationsmæssig tilfældighed, at de overhovedet henf $\varnothing$ res til det processuelle område. Hovedeksemplet her er de materielle regler om påtalefrafald.

I mine bemærkninger skal jeg ber $\varnothing$ re begge sider af sp $\phi$ rgsmålet.

2. Først de processuelle bestemmelsers indflydelse på muligheden for i den konkrete sag at konstatere, hvorvidt betingelserne for at pålægge en bestemt sanktion er til stede.

Dette spørgsmål er komplekst.

For det første er konstateringen af sanktionsforudsætningerne en sammensat proces: Der skal ske oplysning af faktum. - Dette faktum skal vurderes under en retlig synsvinkel (subsumptionen). - Falder bevisf $\varnothing$ relsen og subsumptionen ugunstigt ud for sigtede, skal der på grundlag af en række forskelligartede oplysninger foretages et valg af sanktion. - Er denne sanktion kvantitativt bestemt, skal der endvidere ske en strafudmåling.

For det andet indebærer udtrykket ,,indflydelse“ eller „,betydning“ tre muligheder: De processuelle bestemmelser kan være fremmende, modvirkende eller indifferente i forhold til konstateringen af strafforudsæetningerne.

Med tre varianter i subjektet og fire i objektet er grundsp $\phi$ rgsmålet dermed spaltet op i 12 partielle problemstillinger. - Lykkeligvis kan de dog næppe tillægges lige stor betydning alle 12.

De bestemmelser, der må karakteriseres som indifferente i forhold til den materielle strafferet, omtales samlet til sidst i dette afsnit.

Gruppen af processuelle bestemmelser, som fremmer den rette 
strafferetlige subsumption, er overskuelig og kan hurtigt beskrives. Det drejer sig i første række om kravene til de juridiske dommeres kvalifikation, suppleret af de bestemmelser om forholdet mellem lægdommere og juridiske dommere, der sikrer, at

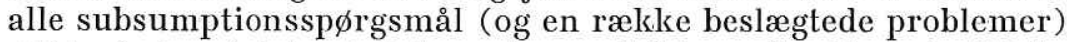
altid afg $\phi r e s$ i det mindste under medvirken af rettens juridiske medlemmer. En yderligere garanti ligger i hele retsmiddelsystemet, der sikrer to instans-pr $\varnothing$ velsen som den almindelige ordning. I $\phi$ vrigt fremtræder vort appelsystem også som en central, supplerende garanti $\mathrm{i}$ henseende til såvel den rette vurdering af faktum som - især - sanktionsfastsættelsen. (Efter manuskriptets udarbejdelse er jeg blevet opmærksom på, at i tilslutning til appelsystemets generelle garanti fortjener også retsplejelovens regler om begrundelse af straffedomme - $\S \S 218$ stk. 1 og 929 stk. 2, cfr. § 911 - særlig fremhævelse som et væsentligt processuelt bidrag til sikring af såvel den gennemarbejdede bevisf $\phi$ relse som den korrekte subsumption og sanktionsfastsættelse).

Et par af de opstillede grupper er formentlig helt tomme. Det drejer sig om bestemmelser, hvis virkning skulle bestå i en modvirken af sanktionsvalg og strafudmåling. Sådanne regler kan, for mig at se, ikke påpeges. — En rigoristisk gennemf $\varnothing$ relse af partsprincippet kunne have en hæimmende virkning $\mathrm{i}$ henseende til sanktionssp $\phi$ rgsmålet. Men netop på dette område gøres der i den gældende procesordning betydelige fravigelser fra princippet.

Endelig må det tilføjes, at spørgsmålet om strafudmåling i det hele afhænger, dels af den faktiske oplysning af det påsigtede forhold, og dels de personlige oplysninger om sigtede. Der er således ingen grund til at behandle spфrgsmålet om, hvilke regler der måtte fremme strafudmålingen særskilt.

Tilbage bliver herefter fire grupper:

- hvilke regler fremmer oplysningen og vurderingen af sagens faktum?

- og hvilke modvirker?

- hvilke modvirker den retlige subsumption?

- hvilke fremmer den rette sanktionsfastsættelse?

De to f $\varnothing$ rste spørgsmål, der vedrører oplysningen og vurderingen af faktum, må afgjort regnes for de vigtigste. Ganske vist er bevisspørgsmålet ikke fremtrædende i det store flertal af vore straffesager. Men netop de sager, hvor beviset er tvivlsomt, ligger i straffeprocessens frontområde. Det er først og fremmest på grundlag af disse sagers regulering og forl $\phi b$, det straffeprocessuelle system må vurderes.

Den materielle strafferet forudsætter en konstatering af, hvorvidt de faktiske forudsætninger for at pålægge straf er til stede. 
Indholdet af denne konstatering kan karakteriseres på følgende måde:

a) Alle de tilfælde, hvor de påkrævede faktiske momenter i en forbrydelses realisation er til stede, b $\phi \mathbf{r}$ ende med, at gerningsmanden kendes skyldig.

b) Ingen af de tilfælde, hvor ikke samilige faktiske forudsætninger er til stede, b $\phi \mathbf{r}$ f $\varnothing \mathrm{re}$ til en skyldig-kendelse.

Dette dobbelte formål finder i $\phi$ vrigt tilsvarende udtryk (ikke med hensyn til straf, men vedrørende strafforfølgning) i Rpl. § $711 \mathrm{om}$ anklagemyndighedens pligt til at sørge for, såvel at strafskyldige personer drages til ansvar, som at ikke-strafskyldige holdes fri for forf $\phi$ lgning.

En processuel bestemmelse (eller et sæt af processuelle regler) kan således bidrage til oplysningen og vurderingen af faktum på to måder, alt efter om den fremmer, at objektivt skyldige erklæres for skyldige, eller skærmer objektivt uskyldige mod en skyldig-kendelse.

Oftest vil en straffeprocessuel regel have indflydelse på begge disse formål samtidig. Dette gælder til eksempel reglerne om vidnetvang, syn og sk $\varnothing$ n, mundtlighed og umiddelbarhed. Mindre centralt, men i samme forbindelse står reglerne om protokollation, afhøring af børn (her spiller dog også andre hensyn ind), bestemmelserne i Rpl. $\S \S 873$ og 875 om dommerens sp $\varnothing$ rgsmål under afh $\phi$ ringer, og reglen i $\S 850$ om domsforhandlingens enhed. Også bestemmelserne om sigtedes pligt til at være til stede under domsforhandlingen ( $R p l$. $\S \S 846 \mathrm{ff}$ ), og de særlige bestemmelser til im $\varnothing$ degåelse af bevisforspildelse (Rpl. $\S \S 806$ stk. 3, 839 stk. 1) kunne nævnes som nogle eksempler blandt mange.

Problemet opstår imidlertid, hvor de to formål kommer i konflikt med hinanden. Skulle de processuelle regler indrettes, så de $i$ videst muligt omfang bidrog til at realisere den materielle strafferet, måtte det i denne sammenhæng føre til et krav om den mest hårfine afbalancering mellem de to formål, således at afvigelserne i begge retninger blev færrest mulige. En regel, hvis virkning til eksempel var, at $2 \%$ af alle skyldige blev frifundet, og $2 \%$ af de uskyldigt sigtede blev d $\phi \mathrm{mt}$, ville således være mere adækvat end en regel, hvorefter $10 \%$ skyldige gik fri, mens $1 \%$ uskyldige blev d $\varnothing \mathrm{mt}$. I det f $\varnothing$ rste tilfælde har den materielle strafferet ikke fundet sin virkeligg $\varnothing$ relse i $4 \%$ af samtlige sager, i det andet er fravigelsen $11 \%$.

Imidlertid hviler vor procesordning som bekendt ikke på dette grundlag. De to formål er ikke ligeværàige, tværtimod. Af let forståelige grunde ser man hellere, at 10 skyldige går fri, fremfor at 1 uskyldig d $\varnothing$ mmes. Denne holdning manifesterer sig i en række bestemmelser, hvoraf den vigtigste er bevissætningen in dubio 
pro reo, der sammen med de $\phi$ vrige kan sammenfattes i princippet favor defensionis (bl. a. sigtedes adgang til det sidste ord under domsforhandlingen, forbudet mod reformatio in peius, og reglerne om genoptagelse; jfr. Rpl. §§ 882, 960 stk. 3,976 og 977). At ordningen $b \phi \mathbf{r}^{\circ}$ være denne, skal så sandelig ikke betvivles. Men i analysen kommer man ikke uden om, at netop in dubio pro reo og favor defensionis-principperne for så vidt kan være en hæmmende faktor for den materielle strafferets virkeligg $\phi$ relse i den konkrete sag.

En række bestemmelser bidrager temmelig ensidigt til varetagelse af det første formål (domfældelse af objektivt skyldige), uden at de dog kan siges at være i strid med det andet formål (frifindelse af uskyldige). Der tænkes herved på den række af tvangsforanstaltninger, der under efterforskningen kan iværksættes til sikring af beviser; det vil sige besigtigelse, beslaglæggelse, telefonaflytning, ransagning og kollusionsarrest. I det omfang der er tale om tvangsforanstaltninger over for den sigtede selv, vil det $\mathrm{i}$ almindelighed dreje sig om beviser, der taler til ugunst for sigtede; ellers var der jo ingen grund til at anvende tvang. Et klart eksempel er således anholdelse og fængsling til imødegåelse af kollusionsfare. Her står det ganske klart, at det er sigtedes kollusionsvirksomhed til sin egen fordel, der kan give grundlag for den processuelle frihedsber $\varnothing$ velse. Den modsatte situation er unægtelig også svær at forestille sig i praksis; og den kan i hvert fald ikke give anledning til fængsling, selv om den i $o g$ for sig falder inden for ordlyden af Rpl. 780, litra c. Drejer det sig om tvangsforanstaltninger over for trediemand (ransagning, beslaglæggelse, vidnetvang og eventuelt besigtigelse), kan det i princippet i hvert fald - ske til varetagelse af begge de to nævnte formål.

Andre bestemmelser tager alene sigte på det andet formål (frifindelse af uskyldige). Som eksempler kan nævnes Rpl. $\S 766$, stk. 2, om forbud mod tvang over for en sigtet; eller $\S 767$, stk. 2, hvorefter løfter, urigtige foregivender eller trusler ikke må anvendes. „Ej heller må afh $\varnothing$ ringen forlænges i det $\varnothing$ jemed at fremkalde en tilståelse“. Også Retsplejelovens afstandtagen fra tidligere tiders tilståelsesarrest må $\mathrm{i}$ alt væsentligt ses som et fors $\phi \mathrm{g}$ på at hindre domfældelse af uskyldige personer. Sensationelle tilfælde af denne art havde fundet sted i forrige århundrede, og de nævntes ofte i debatten forud for Retsplejeloven.

Man kunne for så vidt anf $\varnothing$ re, at hele det akkusatoriske system, med alt hvad dette indebærer og medf $\phi$ rer (partsprincippet, anklageprincippet, forsvarerordningens udbygning etc.) efter sin hensigt skulle bidrage til $\phi$ get sikkerhed i bevisvurderingen, ved at modvirke et alt for kraftigt engagement hos dommeren med den deraf muligt følgende psykologiske præjudice. Derimod må 
det vel anses for tvivlsomt, om den akkusatoriske strafferetspleje er mere velegnet end den inkvisitoriske, når det gælder selve oplysningen af faktum.

3. Der er nu omtalt en række eksempler på bestemmelser, der (på den ene eller anden måde) må karakteriseres som fremmende for oplysningen og vurderingen af faktum. - En betydningsfuld undtagelse var principperne in dubio pro reo og favor defensionis.

Foruden disse principper er der imidlertid adskillige andre regler, der må beskrives som klart hæmmende for den faktiske oplysning af straffesagen. Der tænkes herved på bestemmelserne om vidneudelukkelse og vidnefritagelse ( $R$ pl. $\left.\S \S 169 \_173\right)$, samt - ikke mindst - sigtedes ret til at undlade at afgive forklaring i sin egen sag (Rpl. $\S \S 765$ stk. 2, 807 stk. 3, 868 stk. 1). Hensynet til den lovbestemte tavshedspligt, og $\phi$ nsket om at befri vidner for en urimelig indre konflikt, har f $\phi \mathbf{r t}$ til, at man renoncerer på sagens oplysning. Reglerne om vidneudelukkelse og -fritagelse er imidlertid undergivet skarpe og relativt snævre begrænsninger. Vigtigere er derfor sigtedes ret til at nægte at afgive forklaring - en ret, der ikke er direkte begrænset. Baggrunden for denne rettighed, der af mange anses for fundamental, må formentlig søges i mere irrationelle betragtninger, der historisk har deres rod i angelsaksisk retspleje. Den praktiske betydning af bestemmelsen $b \phi r$ dog ikke overvurderes; det almindelige er unægtelig, at sigtede udtaler sig. Det er næppe heller forunderligt. Den (objektivt) uskyldige vil $\mathrm{i}$ almindelighed være $\mathrm{h} \phi \mathrm{j}$ st interesseret $\mathrm{i}$ at rense sig gennem sin forklaring. Og den (objektivt) skyldige vil i almindelighed være interesseret $i$ at gebærde sig således, som uskyldige formodes at g $\phi$ re det.

Blandt de bestemmelser, der modvirker den fuldstændige oplysning af faktum, bør også omtales regler om summarisk behandling med indskrænkelse af bevisf $\phi$ relsen i tilståelsessager (Rpl. $\S 925,935,868$ stk. 8). Man må dog anse dette eksempel for mindre væsentligt. I det mindste for statsadvokatsagernes vedkommende er den summariske behandling omgærdet af så mange garantier, at disse bestemmelser snarere må henf $\phi \mathrm{res}$ til den gruppe, der betegnes som indifferent i forhold til den materielle strafferets virkeligg $\varnothing$ relse.

4. Visse processuelle bestemmelser kan efter omstændighederne være egnede til at modvirke den korrekte strafferetlige subsumption af et i $\phi$ vrigt veloplyst forhold.

I Rpl. $\S 908$ stk. 4 omtales i begyndelsen f $\phi$ lgende undtagelse fra det i dansk straffeproces gældende anklageprincip: „Derimod er retten ikke udelukket fra at henf $\varnothing$ re det påtalte forhold under 
en anden strafbestemmelse end den, statsadvokaten har påstået anvendt....". Umiddelbart synes denne bestemmelse at indebære en vis garanti for, at subsumptionstvivl, der resulterer i retsvildfarelser hos anklagemyndigheden, kan korrigeres af retten. I praksis reduceres bestemmelsens betydning imidlertid væsentligt, idet det under henvisning til anklageprincippet (Rpl. $\S 908$ st. 3) fordres, at alle faktiske momenter i den nye subsumption skal være påberåbt. Dette vil kun yderst sjældent være tilfældet, og frifindelse må derfor ske.

I sådanne tilfælde er der klart tale om, at den processuelle maxime, anklageprincippet, i forbindelse med reglerne om stiltiende og bindende påtalebegrænsninger, direkte modvirker virkeliggørelsen af den materielle strafferet. - På den anden side bærer den materielle strafferet sin del af ansvaret, netop fordi den skildrede situation forudsætter subsumptionstvivl; tvivl om subsumption vil i reglen hidrøre fra uskarphed $\mathbf{i}$ den materielle strafferets beskrivelse af gerningsindholdene. Frifindelser på grund af subsumptionstvivl kendes da også kun fra berigelsesforbrydelserne og de $\emptyset$ vrige formuekrænkelsers område.

Et andet eksempel finder man i den praktiske betydningsfulde bestemmelse om summarisk behandling af tilståelsessager, Rpl. § 925. I fordringen om, at sigtedes tilståelse skal være uforbeholden, indlægges undertiden en forudsætning om, at han skal være enig i den strafferetlige karakterisering af det påsigtede og tilståede forhold. Sigtedes udtrykkelige opfattelse af subsumptionen må efter dette synspunkt ikke afvige fra rettens, dersom sagen skal kunne fremmes efter $\S 925$. Denne synsmåde har kun delvis fodfæste i praksis. Men følges den, kan den siges at indebære en vis risiko for den rette subsumption. Betydningen er i dette tilfælde dog langt mindre end i det foregående (om anklageprincippet), fordi virkningen af sigtedes afvigende opfattelse af subsumptionen i det h $\varnothing$ jeste kan f $\varnothing \mathrm{re}$ til, at sagen må fremmes ved almindelig domsmandsret, fremfor efter $\S 925$.

Til sidst i denne gruppe skal også anføres betydningen af lægmænds deltagelse i vor strafferetspleje.

At sætte ikke-jurister til at afgøre de retlige subsumptionsspørgsmål må vel umiddelbart indebære en vis fare, hvad angår gennemf $\varnothing$ relsen af subsumption i overensstemmelse med den materielle strafferet. $\mathrm{Nu}$ er der jo heller ikke tale om, at lægdommerne er ganske overladt til sig selv i disse spørgsmål. Domsmændene står under stadig retlig vejledning af retsformanden. $\mathrm{Og}$ for nævningernes vedkommende bidrager en lang række bestemmelser (spørgsmålssystemet, retsbelæringen, retsformandens tilkaldelse under rådslagningen og hans mulighed for ved denne lejlighed at tage ordet) til at sikre mod subsumptionsvildfarelser. - For underretssagers vedkommende består der yderligere den 
garanti, at urigtig anvendelse af straffeloven er ankegrund (Rpl. $\S 963$ stk. 1, nr. 1). I nævningesager forudsætter anke, at subsumptionsvildfarelsen kan henf $\varnothing$ res til retsbelæringen eller de stillede spфrgsmål (Rpl. § 945 stk. 1, nr. 2; se dog tillige nr. 1 i samme paragraf, hvorefter rettens undladelse af ved domfældelsen at korrigere nævningernes subsumptionsvildfarelse også kan være ankegrund).

I $\phi$ vrigt kunne lægmandsordningen også tages op inden for de andre grupper, såvel $\mathrm{i}$ henseende til vurderingen af faktum som ved sanktionsfastsættelsen. Nogle ville f. eks. hævde, at nævningeinstitutionen i $h \phi j$ grad modvirker virkeligg $\varnothing$ relsen af den materielle strafferet gennem frifindelser eller anvendelse af strafbortfaldsgrunde på et stærkt f $\varnothing$ lelsesbetonet grundlag. - Spфrgsmålet skal ikke ber $\phi r e s$ nærmere her. Det er højst kompliceret og lader sig formentlig næppe besvare uden inddragelse af en række mere eller mindre irrationelle momenter.

5. Herefter skal kort omtales en gruppe procesregler, der indførtes i 1960 som et direkte fors $\varnothing \mathrm{g}$ på i videre omfang at bidrage til virkeligg $\phi$ relsen af den materielle strafferets forudsætning om en stærkt individualiseret sanktionsfastsættelse; Rpl. $\S 800$ a$800 \mathrm{c}$.

Indgående personundersøgelser og mentalunders $\varnothing$ gelser er i visse sagskategorier blevet betragtet som uomgængeligt n $\varnothing$ dvendige forudsætninger for den rette sanktionsfastsættelse. Personunders $\varnothing$ gelser er således i særlig grad forudsat, hvor der kan blive tale om betinget dom, tiltalefrafald på særlige vilkår samt ungdomsfængsel eller retsf $\varnothing$ lger, der træder i stedet for straf. Efter den nylige ophævelse af ungdomsfængsel, arbejdshus og sikkerhedsforvaring er den sidstnævnte tilfældegruppe $\mathrm{i}$ alt væsentligt blevet overflødig. Også antallet af mentalunders $\varnothing$ gelser må forudses at falde betydeligt, efter ophævelsen af særfængsel og den kraftige beskæring af adgangen til at anvende forvaring.

Bestemmelserne har imidlertid i de forløbne år været et af de klareste eksempler på processuelle bidrag til virkeligg $\varnothing$ relsen af en strafferetlig og kriminalpolitisk sanktionsopfattelse - som i dag ganske vist er på tilbagetog. De to sanktionsformer, betinget dom og tiltalefrafald på vilkår (der funktionelt er højst lig hinanden) vil dog formentlig stadig vinde terræn; og Rpl. $\S 800$ a vil således fortsat være af stor betydning for sanktionsfastsættelsen.

6. I den indledende analyse af udtrykket ,,virkeligg $\varnothing$ relse af den materielle strafferet" blev udgangspunktet taget i sondringen faktum/subsumption/sanktion. Heri ligger imidlertid en forudsætning om, at sagen overhovedet er naet frem til vurdering for 
anklagemyndigheden og domstolene. - Det er imidlertid ingen selvfølge, at sagen når så vidt.

Det må derfor også påpeges, at reglerne om politiets pligt til at efterforske mulige strafbare handlinger (Rpl. § 801), og de hierarkiske klagemuligheder inden for anklagemyndigheden, i $\mathbf{h} \phi \mathbf{j}$ grad er forudsætninger for virkeligg $\varnothing$ relsen af den materielle strafferet.

En anden basal forudsætning for at bringe retsapparatet i anvendelse er, at den sigtede er til stede (udeblivelsesdomme kendes i dansk ret kun i nogle mindre væsentlige undtagelsestilfælde; jfr. Rpl. $\S \S 847$ stk. 2 og 934 stk. 1). De processuelle bestemmelser, der tjener til sikring af sigtedes tilstedeværelse må derfor ses som bidrag til at sikre strafforf $\varnothing$ lgningens gennemf $\varnothing$ relse og dermed den strafferetlige realisering. - Det drejer sig her f $\phi$ rst og fremmest om fængsling til im $\varnothing$ degåelse af unddragelsesfaren (Rpl. § 780, litra a), anholdelse i samme $\varnothing$ jemed (Rpl. $\S \S 768$ ff), hovedparten af de - sjældent anvendte - fængslingssurrogater (Rpl. §§ 785-788), samt formuebeslag (Rpl. §§ 794-796).

På den anden side kan processuelle regler også hindre den materielle strafferets realisering kategorisk, ved overhovedet at afskære påd $\varnothing$ mmelse af en sag. Læren om den negative retskraft (således som den afbalanceres af bestemmelserne om genoptagelse, Rpl. $\S \S 975$ ff) er et hovedeksempel herpå.

7. Flere straffeprocessuelle bestemmelser må karakteriseres som indifferente $\mathrm{i}$ forhold til den materielle strafferet. Det drejer sig for det f $\phi$ rste om en række rent teknisk betonede forskrifter, som Retsplejeloven — i lighed med alle proceslove — indeholder i rigt mål.

Men også mere centrale processuelle bestemmelser må henregnes til den ,indifferente“" gruppe. Som et eksempel kan nævnes princippet i Rpl. § 946 stk. 1, hvorefter tilsidesættelse eller fejlagtig anvendelse af rettergangsregler ikke bevirker ophævelse af en påanket dom, medmindre det måtte antages, at fejlen kunne have betydning for sagens udfald. Denne bestemmelse tager efter sit udtrykkelige indhold netop sigte på de tilfælde, hvor sagens udfald - eller om man vil: virkeligg $\varnothing$ relsen af den materielle strafferet - er upåvirket og upåvirkelig af den tilsidesatte procesregel. Bestemmelsen i § 946 hviler udelukkende på proces$\phi$ konomiske betragtninger.

8. Denne - noget kalejdoskopiske - gennemgang viser, at forholdet mellem de processuelle normer og den materielle strafferets udm $\varnothing$ ntning i den konkrete sag er $h \varnothing j$ st sammensat. Snart er der tale om en fremmende, snart om en modvirkende indflydelse. Undertiden begge dele samtidig, og undertiden ingen af delene. 
Denne konstatering kan ej heller undre, når det betænkes, at de straffeprocessuelle regler fremstår som resultatet af brydningen mellem en række hensyn, hvoraf virkeligg $\phi$ relsen af den materielle strafferet kun er et enkelt, omend det vigtigste i den forstand, at det er dette formål, der overhovedet g $\phi \mathrm{r}$ et straffeprocessuelt system forn $\varnothing$ dent.

9. Som nævnt indledningsvis findes der blandt de bestemmelser, som traditionelt henregnes til straffeprocessen, også sådanne regler der præciserer og supplerer den materielle ret, forstået som et samlet strafferetligt og kriminalpolitisk system.

Dansk rets anvendelse af opportunitetsprincippet er meget vidtgående. Omkring en trediedel af vore straffesager afg $\phi$ res ved påtalefrafald efter reglerne i Rpl. $\S \S 721,723$ og 723 a. (Hertil kommer et ukendt antal af bagatelsager, der sluttes uformelt ved politiets såkaldte ,rapporteftergivelse“). Det straffeprocessuelle påtalefrafaldsinstitut udg $\phi \mathbf{r}$ således et overordentlig væsentligt supplement til den kriminalretlige sanktionslære. Dette gælder i særlig grad, for så vidt der er tale om påtalefrafald på vilkår (Rpl. § 723 a). Den funktionelle forskel mellem et påtalefrafald på vilkår og en betinget dom (der kan indeholde ganske de samme vilkår) er ringe, især hvor den betingede dom afsiges i en sag, der fremmes efter Rpl. § 925.

Også på andre punkter indeholder straffeprocessen sanktioner, der supplerer kapitlerne 6-10 i Straffeloven. Om bødevedtagelse i politisager hedder det således udtrykkeligt i Rpl. § 936 stk. 1, at en eventuel fastsættelse i selve strafbestemmelsen af b $\varnothing$ dens størrelse ikke er bindende. Dette har dog for tiden kun praktisk betydning i forhold til enkelte bestemmelser i særstraffelovgivningen (jfr. Ikrftl. § 6 stk. 1). — Derimod kan b $\varnothing$ deforelægget (Rpl. § 931) ikke anf $\varnothing$ res i denne sammenhæng. Her er der blot tale om en særlig, summarisk og udenretlig gennemf $\varnothing$ relse af strafforf $\varnothing$ lgningen, ikke et supplement til eller en udvidelse af straffelovens sanktionsforskrifter.

Inden for fængslingsområdet kan der peges på en anden form for samspil mellem de processuelle og de materielle normer. Visse former for varetægtsfængsling anteciperer funktionen af den kriminalretlige sanktion. Der tænkes herved navnlig på gentagelsesarrest og retshåndhævelsesarrest (Rpl. $\S 780$, litra b og d).

Selv om gentagelsesarrest undertiden kan anvendes i rent processuelt $\phi$ jemed (d.v.s. for at f $\varnothing \mathrm{re}$ selve straffesagen igennem til en afg $\phi$ relse), er dens hovedfunktion dog af udpræget specialpræventiv (uskadeligg $\varnothing$ rende) karakter.

Endnu klarere stiller det sig for retshåndhævelsesarrestens vedkommende. Det har lige siden indf $\varnothing$ relsen i 1935 voldt vanskeligheder at opstille en sprogligt klart formuleret begrundelse for 
denne omstridte bestemmelse. Den synes mere at have været båret oppe af fornemmelser end af egentligt rationelle argumenter. Klarest i sin karakteristik af retshåndhævelsesarresten er efter min opfattelse Hurwitz, der beskriver den som ,en provisorisk anordnet frihedsstraf". Man kunne hertil føje, at der tilmed er tale om en foregreben straffuldbyrdelse på et klart repressivt grundlag. Anderledes kan man næppe beskrive en regel om frihedsber $\phi$ velse $f \phi r$ endelig dom med det formål, at de $\phi$ vrige samfundsborgere ikke skulle få indtryk af ,manglende Alvor og Konsekvens i Haandhævelsen".

Blandt de materielt betonede regler i straffeprocessen findes også eksempler fra fuldbyrdelsesreglerne.

Her $b \phi r$ det $f \phi r s t$ påpeges, at samtlige bestemmelser om fuldbyrdelse af straffedomme kan siges at bidrage til at virkeligg $\phi r e$ den materielle strafferet på en ganske håndgribelig måde. Det er imidlertid ikke denne indlysende funktion, der skal omtales her.

De fleste bestemmelser om fuldbyrdelse har fået deres plads uden for processen, i den strafferetlige sanktionslære. Denne opdeling - der i $\phi$ vrigt af viger fra systematikken i flere andre europæiske lande - er rent traditionelt bestemt og er et af de mange eksempler på glidende overgange og overlapninger mellem procesretten og strafferetten som videnskabelige og pædagogiske discipliner.

Retsplejeloven indeholder dog i sit ottende afsnit en række bestemmelser om fuldbyrdelse af straffedomme. De fleste er af rent processuelt indhold (f. eks. om frister, pågribelse, indstilling vedrørende benådning etc.). Men her ud over findes der også enkelte bestemmelser af materiel karakter. Dette gælder således reglen i Rpl. § 1001 stk. 2 om udsættelse med afsoningen, hvor denne ville være uforholdsmæssig hård på en måde, der ligger uden for straffens $\varnothing$ jemed. I Rpl. $\S 1005$ finder man en praktisk vigtig bestemmelse om anteciperet sanktionsvalg over for pr $\phi$ vel $\phi$ sladte, prøveudskrevne og personer, der er betinget benådet.

De anførte eksempler viser således, at procesreglerne kan supplere den materielle strafferets sanktionssystem på forskellig måde. Dels ved en art anteciperet fuldbyrdelse. Dels ved at opstille alternative og supplerende sanktionsmuligheder. Og dels gennem regler, der begrænser selve sanktionsanvendelsen.

10. En mindre håndgribelig, men afgjort betydningsfuld, relation mellem procesreglerne og det kriminalretlige system findes i princippet om retsplejens offentlighed (Rpl. $\S \S 29-32$, jfr. herved $\S 1017$ ).

Her tørner henholdsvis almenpræventive og specialpræventive synspunkter sammen. På den ene side hævdes offentlighedsprincippet at være et naturligt, og måske ligefrem nødvendigt led i 
strafferetsplejens bidrag til den almenpræventive effekt. Dels skabes der gennem sagernes omtale røre om straffebestemmelserne, og dermed også for $\varnothing$ get kendskab til dem. Og dels kan den offentlige omtale af en mulig straffesag opfattes som en afskrækkende faktor på linie med selve straftruslen. - Rigtigheden af disse betragtninger kan dog ingenlunde anses for utvivlsom.

Givet er det derimod, at i den konkrete sag kan offentlighedsprincippet tilf $\varnothing$ je den tiltalte stor skade, især gennem den middelbare offentlighed, d.v.s. pressens referater. Ofte påf $\phi$ res der tiltalte en betydelig defami gennem sagens omtale. Og denne virkning kan efter omstændighederne bidrage til at hindre den tilstræbte resocialisering og dermed få karakter af en direkte kriminogen faktor. Retsplejelovens adgang til at suspendere offentlighedsprincippet ud fra sådanne betragtninger er formuleret yderst snævert: „Det skal ikke være aldeles udelukket“ at lukke d $\varnothing$ rene, fordi tiltalte ellers ville blive tilf $\varnothing$ jet en „uforholdsmæssig stor lidelse“" (Rpl. § 29 stk. 4, nr. 1). Næsten tilsvarende regler gælder om navne- og referatforbud (Rpl. § 31 stk. 3). - De særlige regler om „God presseskik ved omtale af straffesager“, der i 1960 blev vedtaget af pressens organisationer, og siden er blevet administreret af Dansk Pressenævn, synes i denne sammenhæng ofte at fungere utilfredsstillende.

En stillingtagen til problemet - og dermed en besvarelse af spørgsmålet, hvorledes de processuelle regler om offentlighed bedst bringes i samklang med det kriminalretlige system - er vanskelig. Dels fordi der savnes konkrete unders $\varnothing$ gelser af offentlighedsprincippets mulige betydning for almenpræventionen. Og dels fordi de kriminalpolitiske synspunkter vedrørende præventionen er mindre afklarede og specielt for tiden synes at være i opbrud.

I international sammenhæng kan det tilf $\varnothing j e s$, at mens den Europæiske Menneskerettighedskonvention i sit udspring og sin formulering klart bygger på offentlighedsprincippet som en garanti for sigtede, har der i Domstolens og Kommissionens praksis været en tilbøjelighed til at $s \varnothing$ ge at begrænse princippets rækkevidde.

11. De hidtil fremf $\phi$ rte betragtninger har rettet sig mod vor straffeprocesordnings nuværende stade i forhold til den materielle strafferet, altså for så vidt en rent statisk analyse. Man kunne imidlertid også anskue spørgsmålet under en dynamisk udviklingsmæssig synsvinkel. Spфrgsmålet kan herefter stilles således: Sker der en løbende tilpasning af de processuelle bestemmelser i takt med den strafferetlige og kriminalpolitiske udvikling? 
Dette problem kan dels betragtes i forhold til den hidtidige udvikling; og dels f $\varnothing$ rer det frem til sp $\varnothing$ rgsmålet om, hvorvidt der i dag kan peges på særlige områder, hvor strafferetsplejen halter bagefter.

I de seneste femten år er der givet i alt seksten ændringslove til Retsplejelovens straffeprocessuelle bestemmelser. Heraf har de tolv været af overvejende teknisk, organisatorisk karakter. De resterende omhandler følgende sp $\varnothing$ rgsmål:

- Person- og mentalunders $\varnothing$ gelser

- Vilkår for påtalefrafald

- Varetægtsfængsling o. a.

- Vidnereglerne

- Overførsel af en række lovovertrædelser til politisagsbehandling.

Bortset fra vidnekapitlet afspejler disse bestemmelser, der for flertallets vedkommende har været omtalt i det foregående, to kriminalpolitiske hovedtendenser:

Individualiserende sanktionsfastsættelse (Rpl. $\S \S 723$ a, 800 a -800 c og 1005).

Nedkriminaliseringen af den mindre grove kriminalitet (Rpl. §§ 721 og 723 a, samt bekendtg $\varnothing$ relsen i henhold til $\S 723$ stk. $1 \mathrm{nr} .5 \mathrm{om}$ statsadvokaternes adgang til at meddele påtalefrafald).

Mens de fremtrædende kriminalpolitiske opfattelser tilsyneladende præger straffeproceslovgivningen i et ikke ringe omfang, er der andre sider af udviklingen, hvor de hensigtsmæssige ændringer i det processuelle system ikke synes at indtræde så forholdsvis prompte. Det gælder især omfanget og sammensætningen af den faktisk forekommende kriminalitet.

Fra en nogenlunde stabil periode i efterkrigsårene har forekomsten af den kendte kriminalitet $\mathbf{i}$ forhold til befolkningstallet (kriminalitetsincidensen) været præget af en næsten ubrudt stigning gennem de seneste femten år. Stigningen er i alt væsentligt sket inden for berigelses- og voldskriminaliteten. I det samme tidsrum er bemandingen (i forhold til befolkningstallet) inden for kriminalpolitiet øget noget, omend ikke tilnærmelsesvis af samme st $\varnothing$ rrelsesorden som kriminalitetsincidensen. Opklaringsprocenterne har dog været relativt stabile. Inden for anklagemyndigheden og domstolene har bemandingstilvæksten været aldeles forsvindende.

Hensigten med disse summariske statistiske bemærkninger er at understrege, at de seneste års betydelige kvantitative for $\varnothing$ gelse af kriminaliteten ikke modsvares af en tilsvarende udvidelse af det straffeprocessuelle apparat. Når det samme apparat skal be- 
handle langt flere sager end tidligere, stiller det omfattende krav om tilpasning, om ændring af apparatet. — En vis tilpasning af strafferetsplejen til den for $\varnothing$ gede tilgang har dog fundet sted. Den nylige udvidelse af området for politisagsbehandling er et eksempel herpå. At tilpasningen imidlertid langt fra har været tilstrækkelig, kan ikke betvivles. Dette manifesterer sig f $\varnothing$ rst og fremmest $\mathrm{i}$ den stadige forlængelse af den tid, der medgår til straffesagernes behandling.

\section{Tempoet i strafferetsplejen har flere aspekter.}

Almindelige humane hensyn over for sigtede taler for mest muligt at begrænse perioden med belastende uvished mellem sigtelsens rejsning og dommens afsigelse. Dertil kommer, at mulighederne for at virkeligg $\phi$ re den materielle strafferets intentioner påvirkes af en overdrevent langvarig sagsbehandling. Dels forringes grundlaget for den faktiske oplysning, fordi værdien af de forklaringer, der afgives af vidner og andre, svækkes efter længere tids for $\phi \mathrm{b}$. Og dels er der meget, som taler for, at sanktionens mulige virkning, såvel i specialpræventiv som almenpræventiv henseende, reduceres betydeligt, når straffen f $\phi \mathrm{rst}$ f $\varnothing$ lger længe efter brøden.

Problemet er for så vidt ikke af ny dato, selv om udviklingen unægtelig har accentueret det kraftigt i de seneste årtier. Allerede i Forordningen af 3 . juni 1796 angaaende Rettens vedb $\phi$ rlige og hurtige Pleie trækkes de modstridende hensyn op: „Retfærdighed og Straflovens Øiemærke fordre, at de criminelle Sagers Behandling $b \phi r$ være saa ukunstlet, og Reitens Pleie saa hurtig, som mueligt; dog at samme kan bestaae med den fuldkomneste Sikkerhed om Sagernes tilstrækkelige Oplysning, paa det at Forbryderne ikke skal undgaa den fortiente Straf, og Uskyldighed tillige være betrygget imod Fare, for at miskiendes“.

Skulle man i dag pege på konkrete foranstaltninger, hvorved de processuelle normer i højere grad kunne bidrage til realiseringen af den materielle strafferet, må det væsentligste stadig være tempofremmende forholdsregler. - Jeg tænker her på ændringer af de egentlige retsplejebestemmelser, og ser bort fra de forbedringer, der beror på personaleudvidelser og mere teknisk betonet rationalisering af retsplejeorganernes arbejdsprocesser.

Uden at gå i detailler skal jeg pege på en række muligheder, der dog stedse má ses i lyset af kravet om ,Sagernes tilstrækkelige Oplysning“ og „Betryggelsen imod at Uskyldighed miskiendes".

Man kunne udvide området for bødeforlæg, således at også højere bøder end 600,- kr. kan vedtages udenretligt (Rpl. § 931 stk. 1). Ingen væsentlige garantier for sigtede tilsidesættes ved 
en sådan udvidelse. Han har altid muligheden for gennem ren passivitet at opnå domstolsprøvelse. - Og i forvejen er tiltalespørgsmålet $i$ en lang række sager vedr $\phi$ rende mindre grov kriminalitet henlagt til politimesterens afg $\varnothing$ relse (Rpl. $\S 721$ stk. 1).

En meget væsentlig faktor i de langvarige straffesager er ankebehandlingen. I fængslingssager er ankebehandlingens urimeligt store indflydelse på varigheden konstateret ved en praktisk unders $\varnothing$ gelse fra 1970 . Og der er ingen grund til at formode, at forholdet er bedre i de $\varnothing$ vrige straffesager, snarere tværtimod. Enhver forholdsregel, der letter landsretternes arbejdsbyrde, er derfor særligt betydningsfuld. Dette kunne bl. a. tale for at begrænse ankemuligheden, således at anke af politisager i vidt omfang måske endda fuldstændigt - blev gjort afhængigt af en anden instans-bevilling, administreret efter de sædvanlige retningslinier for sådanne bevillinger. I forvejen kendes denne ordning ved id $\varnothing$ mmelse af ganske små bødestraffe, samt for det tilfælde, hvor man ellers umiddelbart skulle mene, at ankeadgangen var mest påkrævet, nemlig ved udeblivelsesdom (Rpl. §962 stk. 2). Politisagerne udg $\varnothing \mathrm{r}$ i dag ca. en fjerdedel af ankesagerne ved landsretterne.

Absolutte maximumsfrister i forbindelse med straffesagers gennemf $\phi$ relse er sjældent hensigtsmæssige. Problemet har været gennemdr $\varnothing$ ftet specielt med henblik på varetægtsfængsling. Allerede i procesudkastet fra 1899 forkastedes denne tanke, bl. a. ud fra det træffende synspunkt, at maximalfrister rummer en iboende tendens til at blive udnyttet fuldt ud, også i sager hvor det måske havde været mindre påkrrævet. Erfaringer, der langt senere er gjort i Vesttyskland, synes fuldt ud at bekræfte dette synspunkt. Det fortjener dog alligevel overvejelse, hvorvidt der burde indf $\phi$ res en art forældelsesfrister for den tid, der maximalt må hengå mellem sigtelsens rejsning og afsigelse af dom $i$ henholdsvis første instans og ankeinstansen. Sådanne frister ville givetvis virke ansporende for sagsbehandlingen i alle dens faser. - Et Højesteretsmindretal på tre dommere har i $\emptyset$ vrigt for få år siden i en sag om arbejdspladstyveri (UfR 1965, 10; jfr. UfR $1965 \mathrm{~B}$, 152) tillagt den sendrægtige sagsbehandling (over halvandet år) betydning som en strafsuspenderende faktor og givet betinget dom, hvor de ellers ville have givet ubetinget. - Om en ordning med egentlig forældelse kan anses for anbefalelsesværdig, måtle dog kræve en nærmere undersøgelse. Som en væsentlig mindre indgribende forholdsregel kunne man derimod uden betænkelighed ændre de almindelige forældelsesfrister i Strfl. $\S \S 92-95$ således, at ikke sigtelsen men domfældelsen bliver den fristafbrydende begivenhed. 
En anden foranstaltning, afskaffelse af forundersфgelsesinstituttet, er allerede foreslået af Straffeprocesudvalget i udvalgets første betænkning fra september 1971. Denne ændring ville afgjort indebære en tiltrængt modernisering af vor strafferetspleje. Men desværre har det ikke nogen nævneværdig indflydelse på sagsbehandlingen i praksis, eftersom forunders $\varnothing$ gelse - bortset fra tilståelsessager - i forvejen næppe nok anvendes.

Der er utvivlsomt andre områder og måder, hvorpå behandlingstiden i straffesager kan reduceres. Ikke mindst inden for trafiksagerne kunne forenklinger formentlig gennemf $\phi$ res i langt videre omfang end det hidtil er sket.

13. Temaet „De processuelle normers betydning for virkeligg $\phi$ relsen af den materielle strafferet" er meget omfattende og bredt. De her fremf $\phi$ rte betragtninger har derfor også været brede og af skitsemæssig karakter. Emnet rummer rigeligt stof til enkeltundersøgelser på en række punkter.

Emnets aldeles centrale karakter understreger på ny, at straffeprocesretten er den afg $\phi$ rende og n $\phi$ dvendige forudsætning for den materielle strafferets udmøntning. Begge systemer må således bygge på de samme kriminalpolitiske grundtanker. - Dertil kommer, at den systematiske afgrænsning mellem de to discipliner er h $\varnothing$ jst udflydende.

Overvejer man på den anden side forholdet mellem straffeprocessen og den civile retspleje, må det erkendes, at berøringsfladen her er mere begrænset. Der eksisterer et vist fællesskab om den institutionelle ramme, domstolene — et fællesskab, der i $\phi$ vrigt p. gr. a. lægdommerinstitutionen kun er delvis - og om enkelte procesmaximer (især offentlighed, mundtlighed, partsoffentlighed, kontradiktion, reglerne om vidner samt syn og sk $\phi n)$. Men forskellen mellem de to processuelle systemer er dog på en række centrale områder det i $\varnothing j$ nefaldende.

Mine bemærkninger ved denne lejlighed skal derfor munde ud i en understregning af, hvor vigtigt det må være, at den straffeprocessuelle forskning og — ikke mindst — undervisning stedse drives i snæver forbindelse med den materielle strafferet.

\section{Hans Gammeltoft-Hansen.}

